\title{
ECONOMIC INSECURITY AND STRESS AS DETERMINANTS OF COVID-19 PREVENTIVE BEHAVIOUR IN DENPASAR
}

\author{
Kerentanan Ekonomi dan Persepsi Stres Sebagai Determinan Perilaku Pencegahan \\ COVID-19 di Denpasar
}

*Gede Benny Setia Wirawan ${ }^{1,2}$, The Angela Prisilia Taroreh², Dewa Ayu Agung Dwita Arthaningsih², Made Ayu Devi Pita Loka ${ }^{2}$, Ngakan Made Ari Mahardika ${ }^{2}$, Pande Putu Januraga ${ }^{1,3}$

${ }^{1}$ Center for Public Health Innovation, Faculty of Medicine, Udayana University, Denpasar, Indonesia

${ }^{2}$ Puskesmas I Denpasar Timur, Health Department, Denpasar, Indonesia

${ }^{3}$ Department of Public Health, Faculty of Medicine, Udayana University, Denpasar, Indonesia

Correspondence*:

Address: Gedung PS IKM, JI. PB Sudirman, Denpasar, Indonesia | e-mail: benny.wirawan007@gmail.com

\begin{abstract}
Background: The COVID-19 pandemic has constituted concurrent public health and economic crises. An inter-correlation between economic and public health impacts due to the COVID-19 pandemic needs to be studied to improve mitigation measures.

Aims: This study identified a correlation of the economic insecurity and perceived stress with adherence to recommended preventive behaviours

Methods: This across-sectional analytic study was conducted to adults in the working areas of East Denpasar Primary Healthcare Center I. Respondents were selected using consecutive sampling and given a self-administered questionnaire. The research variables included demographic characteristics, economic insecurity indicators, perceived stress, and adherence to handwashing, mask-wearing, physical distancing, and limitation on the social gathering. Correlations, linear regressions, and path analyses were conducted using IBM SPSS 23.0.

Results: As many as 161 respondents of which $34.2 \%$ males were involved had a mean age of $36.31( \pm 7.16)$ years. Sex, job insecurity, income insecurity, and perceived stress were found as independent determinants in females. Female sex and job insecurity was associated with better preventive behaviours with an adjusted $\beta$ value of 0.276 and 0.306 , while income insecurity and perceived stress had the opposite association with a $\beta$ value of -0.247 and -0.224 .

Conclusion: There are correlations between economic insecurity and preventive behavioural practices during COVID-19. It is suggested that public health policies against COVID-19 cover measures of economic safety nets to improve adherence
\end{abstract}

Keywords: behaviour, COVID-19, economic insecurity, perceived stress, prevention.

\begin{abstract}
Abstrak
Latar Belakang: Pandemi COVID-19 merupakan krisis kesehatan dan ekonomi masyarakat yang terjadi bersamaan. Keterkaitan antara dampak ekonomi dan kesehatan masyarakat akibat pandemi COVID-19 perlu dikaji untuk meningkatkan upaya mitigasi.

Tujuan: Penelitian ini mengidentifikasi hubungan antara ketidakamanan ekonomi dan stres yang dirasakan dengan kepatuhan terhadap rekomendasi perilaku pencegahan.

Metode: Penelitian analitik potong lintang ini dilakukan pada orang dewasa di wilayah pelayanan Puskesmas I Denpasar Timur. Sampel direkrut dengan consecutive sampling dan data dikumpulkan dengan kuesioner yang diisi sendiri. Variabel yang diteliti meliputi demografi, indikator kerentanan ekonomi, persepsi stres, kepatuhan mencuci tangan, pemakaian masker, jarak fisik, dan pembatasan aktivitas sosial. Analisa korelasi, regresi linier, dan analisis jalur dilakukan dengan menggunakan IBM SPSS 23.0.

Hasil: Sebanyak 161 responden yang terdiri atas 34,2\% laki-laki memiliki usia rata-rata 36,31 $( \pm 7,16)$ tahun. Jenis kelamin perempuan, kerentanan pekerjaan, kerentanan pendapatan, dan stres yang dirasakan ditemukan sebagai determinan independen. Jenis kelamin perempuan dan kerentanan pekerjaan yang lebih tinggi ditemukan berhubungan dengan perilaku pencegahan yang lebih baik dengan nilai adjusted $\beta$ masing-masing 0,276 dan 0,306. Sementara itu, terdapat hubungan yang yang berlawanan antara kerentanan pendapatan dan persepsi stres dengan nilai $\beta$ masing-masing -0,247 dan -0,224.

Kesimpulan: Terdapat hubungan antara ketidakamanan ekonomi dan praktik perilaku preventif selama pandemic COVID-19. Penelitian ini menyarankan agar kebijakan kesehatan masyarakat terhadap COVID-19 membahas tentang langkah-langkah dalam jaring pengaman ekonomi untuk meningkatkan kepatuhan.
\end{abstract}

Kata kunci: COVID-19, kerentanan ekonomi, pencegahan, perilaku, persepsi stress.

Jurnal Administrasi Kesehatan Indonesia p-ISSN 2303-3592 e-ISSN 2540-9301

Volume 9 No.2 2021 DOI: 10.20473/jaki.v9i2.2021.124-134

Received: (2020-12-09) Revised: (2021-04-24) Accepted: (2021-06-15) Published: (2021-11-28)

Published by Universitas Airlangga in collaboration with Perhimpunan Sariana dan Profesional Kesehatan Masyarakat Indonesia (Persakmi).

This is an Open Access (OA) article distributed under the terms of the Creative Commons Attribution Share-Alike 4.0 International License (https://creativecommons.org/licenses/by-sa/4.0/) 


\section{Introduction}

COVID-19 has been declared a pandemic since March $11^{\text {th }}, 2020$ although the first cases have been reported in China since late 2019 (WHO, 2020c). The effect of this pandemic has been profound, both as public health and economic hazard. Per November $28^{\text {th }}$, 2020, there were 60.5 million confirmed cases and 1.4 million confirmed deaths due to COVID-19 (WHO, 2020b). In the same period, more than 500 thousand COVID-19 cases with more than 16 thousand mortalities occurred in Indonesia (COVID-19 Response Acceleration Task Force, 2020). There were also evidence that these figures were underestimation of the real situation (Wirawan and Januraga, 2021).

In response to the pandemic, the WHO have endorsed some forms of health protocols. These protocols mostly include avoiding crowd, physical distancing, hand hygiene, and mask-wearing (WHO, 2020a). In compliance with these endorsements, the Indonesian government also applies the same protocols to prevent COVID-19 transmission (Andriani, 2020).

However, these health protocols result in negative impacts. The COVID-19 pandemic and the health protocols have created financial hardships. The International Labour Organization (ILO) reported 400 million full-time job loss by June 2020 (ILO, 2020) in which service industries were reported to experience the most severe impacts (Bartik et al., 2020).

Economic insecurity has previously been found to have a correlation with adherence to COVID-19 preventive behaviour. At the beginning of the pandemic, it has been reported that lower income has been a factor affecting adherence to quarantine protocols (Webster et al., 2020).

The deterioration of the mental health has also been an issue during the pandemic. Previous studies have identified correlations between isolation during the quarantine period and financial stress as risk factors of mental health issues including anxiety, depression, and perceived stress (Khan et al., 2020; Roy et al., 2020).

Two other studies have found mental status in turn was associated with compliance to COVID-19 prevention guidelines. One has also discovered that higher perceived stress was associated with fewer adopted physical distancing measures and perceived compliance, indicating the respondents' awareness of inadequate compliance to prevention guidelines (Tang et al., 2020; Zhao et al., 2020).

After the pandemic has occurred for more than 6 months in Indonesia, the level of adherence to recommended preventive behaviours still require further evaluation. Results on the levels of adherence are currently varied from low to very high (Triyanto and Kusumawardani, 2020; Wiranti, Ayun Sriatmi, and Wulan Kusumastuti, 2020).

A little attempt is performed to study the correlation between the economic impact due to COVID-19 and the effectiveness of the public health policies. As Indonesia has currently been suffering economic and health crises, it is important to understand how these crises are intertwined. Thus, this study aimed to identify a correlation of economic insecurity and level of perceived stress with adherence to COVID-19 preventive behaviour in adults in Denpasar, Bali, Indonesia.

\section{Method}

This study was an analytic crosssectional study in adults in the working area of East Denpasar Primary Healthcare Centre I in Denpasar city, Bali, Indonesia. Samples were recruited consecutively from a pool of parents attending schoolchildren immunization events from $13^{\text {th }}$ to $26^{\text {th }}$ September. They were given selfadministered questionnaires in Indonesian while waiting for their children. The 
questionnaires were gathered after the events finished.

The immunization event with researcher participation was attended by approximately 300 students, with as much parents in company. The researchers approached 210 potential respondents during data collection, but only 191 respondents returned the questionnaires. Out of these, 30 questionnaires were excluded because they were incomplete. Finally, 161 respondents were included for analysis.

Data on the demographic characteristics, economic impacts, perceived stress, and COVID-19 preventive behaviour were collected. Economic impact indicators included impacts on job and income insecurities. Impacts on job insecurity were measured with four Likert scales which consisted of no impact, working hour and pay cut, temporary loss (furloughed), and termination. Meanwhile, impacts on income insecurity were measured with three Likert scales from no change, mild, and severe income loss.

The level of stress was measured using ten items in the perceived stress scale (PSS-10). The scale consisted of 10 questions with two subscales: stress level and self-confidence in managing current situation. Questions answered with scale 4 would have an overall score ranging from 0 to 30. PSS-10 was a validated questionnaire in Indonesian and was previously used in some other research (Indira, 2016; Purnami and Sawitri, 2019). Cronbach alpha for PSS-10 in this present study was 0.688 .

Preventive behaviour was measured with questionnaires previously validated with readability test. The questionnaire evaluated respondents' self-reported behaviour on four recommended preventive behaviours, namely social distancing, mask-wearing, handwashing, and physical distancing. Each question was answered in five Likert scales ranging from 'never' to 'very often' which corresponded to scores from 0 to 4 . Inverse scoring was employed for social gathering indicator in which the respondents could answer 'never' that corresponded to score 4 while they could answer 'always' meaning 0 .

The level of adherence was measured by a mean score of these four questions and classified into three groups: adequate (a mean score of 3 or more), inadequate (a mean score of 2 to 2.99), and severely inadequate (a mean score of less than 2). This study used bivariate correlation, multivariate regression, and path analyses in IBM SPSS 23.0.

\section{Result and Discussion}

There were $106(65.8 \%)$ females and $55(34.2 \%)$ males participating in the present study. The mean age was 36.31 $( \pm 7.16)$ years. Most of the respondents (49.1\%) finished high school although a significant number of respondents finished higher education (Table 1).

The majority of the respondents reported a detrimental impact on employment and income due to COVID-19 pandemic and its associated health protocols. Only $45(28.0 \%)$ respondents reported no change in employment while nearly half reported hours and pay cut. From the income aspect, only $26(16.1 \%)$ reported no change, and 102 (63.4\%) respondents reported a severe loss. The mean PSS-10 score was 16.11 ( \pm 5.69 ).

Out of 161 respondents, the mean preventive behaviour score was 12.93 ( \pm 1.54). Most of the respondents answered 'very often' on the frequency of handwashing (63.4\%), mask-wearing $(81.4 \%)$, and 1-meter physical distancing in the public places (54.7\%). However, most of them still reported 'occasional' social gathering (75.8\%). Overall, the majority $(82.6 \%)$ had adequate preventive behaviour.

Overall, the results indicate adults in Denpasar had good COVID-19 prevention practice which can be seen from the preventive behaviour score and the exceeding threshold score. However, there were few that had inadequate $(16.8 \%)$ and even severely inadequate preventive behaviour $(0.6 \%)$.

The majority also reported 'often' or 'very often' to practice handwashing and mask-wearing. However, only a little more 
Table 1. Sociodemographic characteristics of the respondents.

Variables

Sex, n (\%)

Male

$55(34.2)$

Female

$106(65.8)$

\begin{tabular}{ll}
\hline Age (year), mean \pm SD) & $36.31 \pm 7.16$ \\
\hline Education, $\mathrm{n}(\%)$ & \\
Below elementary school & $2(1.2)$ \\
Elementary school & $7(4.3)$ \\
Middle school & $24(14.9)$ \\
High school & $79(49.1)$ \\
Associate degree & $21(13.0)$ \\
Bachelor degree & $25(15.5)$ \\
Post-graduate & $3(1.9)$ \\
Employment insecurity, $\mathrm{n}(\%)$ & $45(28.0)$ \\
No change & $79(49.1)$ \\
Hours/pay cut & $31(19.3)$ \\
Temporary furlough & $6(3.7)$ \\
Termination & $26(16.1)$ \\
\hline Income insecurity, $\mathrm{n}(\%)$ & $33(20.5)$ \\
No change & $102(63.4)$ \\
Mild income loss & $16.11 \pm 5.69$ \\
\hline Severe income loss & $12.93 \pm 1.54$ \\
\hline PSS-10 score, mean \pm SD & \\
\hline Preventive behaviour & $133(82.6)$ \\
score, mean \pm SD & $27(16.8)$ \\
\hline Preventive behaviour, $\mathrm{n}(\%)$ & $1(0.6)$ \\
Adequate & \\
Inadequate & \\
Severely inadequate &
\end{tabular}

than $50 \%$ reported 'very often' to practice physical distancing in 1-2 meters, and more than three quarters reported 'occasional' social gathering. This indicates although the respondents tried to adhere to mask-wearing and hand washing, physical distancing and avoiding the crowd were more difficult to implement.

Previous results imply that compliance with recommended preventive behaviours varied between places and time. Results from studies in North America and Europe show a different level of adherence to preventive behaviours. For example, $83.1 \%$ of the respondents avoided social gathering while $65.5 \%$ maintained 2-meter physical distancing (Coroiu et al., 2020). A study conducted in Ghana has contradictory results that $90 \%$ of the respondents complied with physical distancing in public transport but maskwearing which only $16 \%$ of them practiced (Dzisi and Dei, 2020).

Some previous studies on compliance with COVID-19 health protocol in various regions in Indonesia have shown various results. Two studies in Depok, West Java and Klaten, Central Java have found different results. In Depok, West Java, only $55.8 \%$ of the respondents had good preventive behaviours although the categorization of the behaviours was not clear enough (Wiranti et al., 2020). The other study in Klaten, Central Java, shows similar results to the present findings (Disemadi and Handika, 2020).

Table 2. Correlation matrix between variables.

\begin{tabular}{|c|c|c|c|c|c|c|}
\hline & 1 & 2 & 3 & 4 & 5 & 6 \\
\hline 1. Preventive behaviour & 1 & & & & & \\
\hline 2. Age & 0.024 & 1 & & & & \\
\hline 3. Education & 0.005 & $0.137^{+}$ & 1 & & & \\
\hline 4. Job insecurity & 0.021 & -0.080 & -0.126 & 1 & & \\
\hline 5. Income insecurity & $-0.178^{*}$ & -0.013 & $-0.239^{* *}$ & $0.606^{* *}$ & 1 & \\
\hline 6. Perceived stress & $-0.179^{*}$ & -0.127 & $-0.237^{\star *}$ & $0.318^{* *}$ & $0.348^{* *}$ & 1 \\
\hline
\end{tabular}

${ }^{+} p<0.1 ;{ }^{*} p<0.05 ;{ }^{* *} p<0.01$

Table 3. Multiple linear regression for preventive behaviour scores.

\begin{tabular}{|c|c|c|c|c|c|}
\hline \multirow{2}{*}{ Variables } & \multirow{2}{*}{$\beta$} & \multirow{2}{*}{ B } & \multicolumn{2}{|c|}{ 95\% Confidence Interval } & \multirow[b]{2}{*}{$p$} \\
\hline & & & Lower & Upper & \\
\hline Age & 0.117 & 0.025 & -0.007 & 0.057 & 0.126 \\
\hline Sex, female & 0.276 & 0.892 & 0.407 & 1.377 & $<0.001^{* *}$ \\
\hline Education & 0.010 & 0.014 & -0.190 & 0.218 & 0.895 \\
\hline Job insecurity & 0.306 & 0.594 & 0.243 & 0.945 & $0.001^{* *}$ \\
\hline Income insecurity & -0.247 & -0.500 & -0.876 & -0.123 & $0.010^{*}$ \\
\hline Perceived stress & -0.224 & -0.060 & -0.103 & -0.017 & $0.006^{* *}$ \\
\hline
\end{tabular}

${ }^{+} p<0.1 ;{ }^{*} p<0.05 ;{ }^{* *} p<0.01$ 
Compliance with handwashing and mask-wearing was high (more than $70 \%$ ), while very least respondents practiced the advice of stay-at-home. However, the study did not report on compliance with physical distancing in public places (Disemadi and Handika, 2020). A study conducted from March-April supports the present findings on compliance with handwashing and mask-wearing but shows different results on compliance with physical distancing which was only practiced by around a half of the respondents (Triyanto and Kusumawardani, 2020).

Based on the method and respondent characteristics, some cautions might apply in generalizing the results. Due to the geographic limitation, the results would be most appropriately generalized to residents in Denpasar. The respondents were just limited to parents with children enrolled in elementary schools, excluding adults without children in elementary school.

Finally, the data show an even distribution of both age and education. However, compared to the demographic profile of Denpasar, the median age of the respondents was slightly higher, and the distribution by sex was more dominated by females (Denpasar City Department of Health, 2019).

The results of Spearman's correlation analysis for ordinal variables of preventive behaviours and independent variables which shows a significant correlation of income insecurity and stress with frequency of handwashing and physical distancing practices (Table 2). Higher income insecurity was correlated with less frequent handwashing and physical distancing practices with Spearman's rho of -0.185 and -0.167 , respectively. Similarly, higher perceived stress was significantly correlated with less frequent handwashing and physical distancing with Spearman's rho of -0.220 and -0.190 . A less significant and weaker correlation was found between higher education level and more frequent maskwearing with Spearman's rho of $0.135(p=$ 0.085).

Table 3, the diagonal, displays a correlation matrix between variables. A
Spearman's non-parametric correlation was employed for all pairings because most of the variables were ordinal. The only two numeric variables were PSS-10 and preventive behaviour scores which had non-normal distribution. The result shows two variables were correlated significantly with preventive behaviour scores, namely income insecurity and stress. Higher levels of income insecurity and stress were correlated with lower adherence to COVID-19 preventive behaviours with Spearman's rho of -0.178 and -0.179 , respectively.

There was also an inter-correlation between education level, job insecurity, income insecurity, and stress. Income insecurity was negatively correlated with education level but positively correlated with job insecurity with Spearman's rho of -0.239 and 0.606 , respectively. Perceived stress was significantly correlated with education, job and income insecurities. Higher education level was associated with lower perceived stress while higher job and income insecurities were correlated with higher perceived stress with Spearman's rho of $-0.237,0.318$, and 0.348 , respectively.

Further multiple linear regression discovers more independent correlations between independent variables and preventive behaviour scores. As shown in Table 3, variables independently associated with preventive behaviours were sex, job insecurity, income insecurity, and stress level. Female sex and higher job insecurity were independently associated with better preventive behaviour practices with an adjusted $\beta$ value of 0.276 and 0.306 , respectively. Higher-income insecurity and perceived stress, on the other hand, were associated with lower adherence with an adjusted $\beta$ value of -0.247 and -0.224 , respectively.

However, despite the significant association between independent variables and preventive behaviour scores, only job insecurity was significantly associated with the likelihood of adequate preventive behaviour with an OR value of $6.39(95 \% \mathrm{Cl} 1.248-32.739)$.

A less significant correlation was found between income insecurity and stress level. The respondents who 
reported severe income loss and higher PSS-10 score were less likely to show adequate preventive behaviours with OR of $0.189(95 \% \mathrm{Cl} 0.028-1.253)$ and 0.925 $(95 \% \mathrm{Cl} 0.850-1.008)$, respectively.

Further path analysis, as shown in Figure 1, explains how education, economic insecurity, and perceived stress interrelate each other in determining the practice of COVID-19 preventive behaviours. Apart from its direct correlation with preventive behaviour, job insecurity was an independent determinant of income insecurity and become a determinant of preventive behaviour. Similarly, income insecurity was also an independent determinant of perceived stress. On the other hand, education level, which was not a direct independent determinant of preventive behaviour, was an independent determinant of income insecurity.

The results imply correlations between economic impacts due to COVID19 pandemic and reported preventive behaviours. Furthermore, an independent association occurred between sex, economic impacts, and stress level with overall adherence to preventive behaviour recommendations. The level of education, economic impacts, and stress level were interrelated as shown in Figure 1.

Previous results also highlight perceived impacts of COVID-19 prevention, such as difficulties in providing basic needs, performing work, having entertainment, and building social relations (Andayani, 2020). Some studies have reported on the impacts of COVID-19 pandemic and constraints in the aspects of employment and income (Gupta et al., 2020; Spurk and Straub, 2020). Another previous study points out mental health problems due to the COVID-19 pandemic and social distancing (Park et al., 2020).

While other studies reveal socioeconomic status, including levels of income, education, and employment, was correlated with preventive behaviours (Irigoyen-Camacho et al., 2020; Zhong et al., 2020). To support the findings, this present study further gives evidence on the direct association between economic impacts and adherence to preventive behaviour recommendations.

Current evidence used variables that better describe a current level of socioeconomic status, such as current employment and current income levels. While these variables were correlated with adherence to COVID-19 prevention practices, the current levels of income and employment were fundamentally different from sudden economic insecurity. Some people may currently have a low level of income, which did not change during the COVID-19 pandemic. Some low-income respondents such as retail workers can be categorized under this category. Meanwhile,

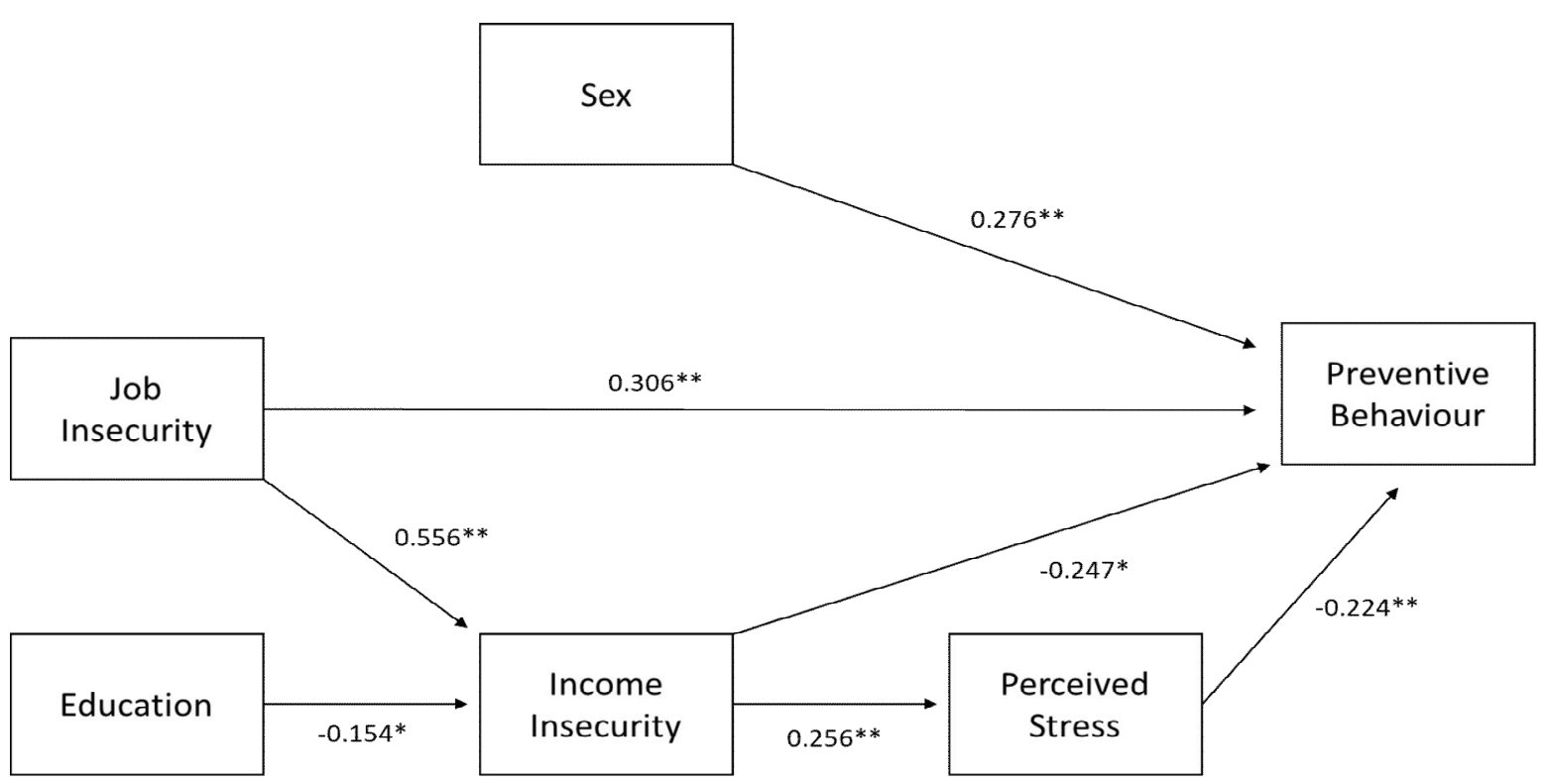

Figure 1. Estimated path model for determinants of COVID-19 preventive behaviors.

Note: ${ }^{*} p<0.05 ;{ }^{* *} p<0.01$ 
sudden economic changes may cause middleincome workers to lose their jobs and income or to face pay cuts.

This distinction between current economic status and change during the COVID-19 pandemic should be emphasized. People nowadays face different day-to-day challenges during the COVID-19 pandemic. Worker with low income may face less financial stress as they will not be affected that much but face more about the COVID-19 infection. Meanwhile, those facing income loss may face financial stress as they may become untenable under the current low economic situation. These different challenges may reflect different behaviours in facing the COVID-19 threats. Unfortunately, however, the current data examined could not reflect these differences as available data were about changes due to COVID19 in terms of economic security without a baseline.

Results from the previous analysis corroborate the notion that mental health was affected not only by severe poverty but also socioeconomic degradation due to the recession. Systematic reviews of studies conducted around 2007-2009 conclude increased perceived stress and depression in people experiencing layoffs in terms of income loss and financial stress. However, those who remained at work were under pressure, stress, and depression due to increased workload due to a loss in the number of workers and fear of employment loss and pay-cuts (Frasquilho et al., 2016; Mucci et al., 2016).

Some recent studies corroborate these earlier findings. Financial stress pandemic and constraints during the COVID-19 may negatively impact one's mental health. Figure 1 shows that income insecurity during the COVID-19 pandemic is the sole independent determinant of stress level among the respondents. The previous results support other studies finding financial stress, loss of income and career setback due to COVID-19 became significant sources of psychological stress (El-Zoghby et al., 2020; Restuborg et al., 2020). This condition applies to people employed in service and entertainment industries (Khan et al., 2020) as the population in the present research took place in Denpasar, Bali, a well-known tourism hub.

Mental health issues, including fear of COVID-19 infection and financial stress, negatively affected adherence to preventive behaviours. Another previous study further claims that perceived stress was negatively correlated with preventive behaviour practices among healthcare workers (Tang et al., 2020). Among the population in China, higher perceived stress was correlated with less frequent COVID-19 prevention practices (Luo et al., 2020).

In line with the previous research findings, someone experiencing more stress and anxiety would behave less cautious by neglecting preventive behaviour. Excessive stress and anxiety may lead someone to have negative coping mechanisms. Someone with somewhat stress and anxiety may be more cautious and aware, but they may not care enough when the stress level exceeds a certain level and thus makes them have negative coping mechanisms, such as denial of preventive behaviours (Luo et al., 2020).

This present study has also found a direct independent correlation between economic insecurities and preventive behaviours, as shown in Figure 1. Other studies support the results by saying that job insecurity was positively correlated with preventive behaviours (Li et al., 2020; Tang et al., 2020). The correlation may occur as non-working people would have fewer chances to engage in activities outside. Another study, on the other hand, explains income insecurity was negatively correlated with preventive behaviour (Irigoyen-Camacho et al., 2020). Income loss may discourage people to adhere to preventive behaviours as those who have income can provide their basic needs (Webster et al., 2020).

The previous results imply that policy-making was somewhat shaped by the belief that conducting an effective public health intervention against COVID19 pandemic encourages the government to sacrifice economic wellbeing, at least for a short term (Guest, del Rio, and Sanchez, 2020). The present results show 
differently by stating that public health interventions, especially relying on compliance with behavioural changes, would be ineffective when public priority relies not only on maintaining the public health but also securing public finances. In other words, public health policies should balance the effectiveness by maintaining economic stability.

Similar recommendations have been expressed previously based on the COVID-19 management in Vietnam. However, the country needs to maintain societal and political stability more (Tran et al., 2020). The present results provide more evident of the economic impacts during the COVID-19 pandemic, that will only be milder when the public health interventions are effective enough to control the pandemic itself. With vaccine rollout, it would also be interesting to see how these factors affect vaccine acceptance as there have been evidence that distrust in government was a barrier to vaccine acceptance (Wirawan et al., 2021).

At the end, this study emphasizes that behaviour science is complex, and predicting determinants for certain behaviours require more variables than what are available in this study. More variables, such as attitudes, beliefs, and other psychological measures, are proven to get correlated with COVID-19 preventive behaviours although they are not accounted for in this study.

\section{Conclusion}

Economic insecurity during the COVID-19 pandemic had a correlation with its public health protocols to prevent the transmission among the population in Denpasar, Bali, Indonesia. Job and income insecurities were as the independent determinants of preventive behaviours, along with perceived stress and sex. The path modelling further shows education as an indirect determinant of income insecurity.

The results imply responses to the COVID-19 pandemic should not focus on mitigating the transmission in a tunnel vision. Instead, these should balance economic stability to enhance the effectiveness of public health interventions, especially relying on public behavioural changes.

\section{Abbreviations}

WHO: World Health Organization; SD: Standard Deviation; COVID-19: Coronavirus Disease of 2019; PSS: Perceived Stress Scale; Puskesmas: Pusat Kesehatan Masyarakat; OR: Odds Ratio.

\section{Declarations}

\section{Ethics Approval and Consent Participant}

All respondents have given informed consent forms for their participation in this study. Those who agreed to join were required to sign the forms. During the data collection, the researchers were standby to provide any additional information of the research procedures if necessary. Respondents were free to cancel their participation at any time. This study has obtained an ethical clearance from Faculty of Medicine, Udayana University/ Sanglah General Hospital Ethics Commission (No. 2230/UNUN.14.2.2.VII.14/LT/2020).

\section{Conflict of Interest}

The authors declare that there is no significant competing financial, professional, or personal interests that might have affected the reporting of results in this study.

\section{Availability of Data and Materials}

Data and material research can be provided upon reasonable request to corresponding author.

\section{Authors' Contribution}

GBSW conceptualized the study and created the methodology; TAPT, DAADA, MADPL, NMAM, and PPJ wrote, reviewed, and edited the manuscript; GBSW wrote the original draft.

\section{Acknowledgment}

We would like to thank dr. Yanto Hartanto and other medical staffs in Puskesmas I Denpasar Timur, for their support and all the respondents who participated in this study. 


\section{References}

Andayani, T. R. (2020). Sumber informasi serta dampak penerapan pembatasan sosial dan fisik pada masa pandemi COVID-19: Studi eksploratif di Indonesia. Psikologi Sosial, 18(59). https://doi.org/10.7454/jps.2020.xx

Andriani, H. (2020). Effectiveness of Large-Scale Social Restrictions (PSBB) toward the New Normal Era during COVID-19 Outbreak: a Mini Policy Review. Journal of Indonesian Health Policy and Administration, 5(2), 61-65. https://doi.org/10.7454/ihpa.v5i2.4001

Bartik, A. W., Bertrand, M., Cullen, Z., Glaeser, E. L., Luca, M., and Stanton, C. (2020). The impact of COVID-19 on small business outcomes and expectations. Proceedings of the National Academy of Sciences of the United States of America, 117(30), 17656-17666.

https://doi.org/10.1073/pnas.2006991 117

Coroiu, A., Moran, C., Campbell, T., and Geller, A. C. (2020). Barriers and facilitators of adherence to social distancing recommendations during COVID-19 among a large international sample of adults. In PloS one (Vol. 15, Issue 10, p. e0239795). https://doi.org/10.1371/journal.pone.0 239795

COVID-19 Response Acceleration Task Force. (2020). Distribution Maps (Indonesian).

https://covid19.go.id/peta-sebaran

Denpasar City Department of Health. (2019). Profil Kesehatan Kota Denpasar Tahun 2019.

Disemadi, H. S., and Handika, D. O. (2020). Community compliance with the covid-19 protocol hygiene policy in Klaten Regency, Indonesia. Legality: Jurnal IImiah Hukum, 28(2), 121-133.

https://doi.org/10.22219/ljih.v28i2.121 80

Dzisi, E. K. J., and Dei, O. A. (2020). Adherence to social distancing and wearing of masks within public transportation during the COVID 19 pandemic. Transportation Research Interdisciplinary Perspectives, 7, 100191.

https://doi.org/10.1016/j.trip.2020.100 191

El-Zoghby, S. M., Soltan, E. M., and Salama, H. M. (2020). Impact of the COVID-19 Pandemic on Mental Health and Social Support among Adult Egyptians. Journal of Community Health, 45(4), 689-695. https://doi.org/10.1007/s10900-02000853-5

Frasquilho, D., Matos, M. G., Salonna, F., Guerreiro, D., Storti, C. C., Gaspar, T., and Caldas-De-Almeida, J. M. (2016). Mental health outcomes in times of economic recession: A systematic literature review Health behavior, health promotion and society. BMC Public Health, 16(1). https://doi.org/10.1186/s12889-0162720-y

Guest, J. L., del Rio, C., and Sanchez, T. (2020). The Three Steps Needed to End the COVID-19 Pandemic: Bold Public Health Leadership, Rapid Innovations, and Courageous Political Will. JMIR Public Health and Surveillance, 6(2), e19043. https://doi.org/10.2196/19043

Gupta, S., Montenovo, L., Nguyen, T., Rojas, F. L., Schmutte, I., Simon, K., Weinberg, B., and Wing, C. (2020). Effects of Social Distancing Policy on Labor Market Outcomes. In NBER Working Paper Series (No. 27280). https://doi.org/10.3386/w27280

ILO. (2020). COVID-19: Public employment services and labour market policy responses. https://doi.org/10.1177/00221465134 79002

Indira, I. E. (2016). Stress Questionnaire: Stress Investigation From Dermatologist Perspective. Psychoneuroimmunology in Dermatology, 141-142.

Irigoyen-Camacho, M. E., Velazquez-Alva, M. C., Zepeda-Zepeda, M. A., Cabrer-Rosales, M. F., Lazarevich, I., and Castaño-Seiquer, A. (2020). Effect of income level and perception of susceptibility and severity of covid19 on stay-at-home preventive 
behavior in a group of older adults in Mexico City. International Journal of Environmental Research and Public Health, 17(20), 1-16. https://doi.org/10.3390/ijerph1720741 8

Khan, K. S., Mamun, M. A., Griffiths, M. D., and Ullah, I. (2020). The Mental Health Impact of the COVID-19 Pandemic Across Different Cohorts. International Journal of Mental Health and Addiction. https://doi.org/10.1007/s11469-02000367-0

Li, S., Feng, B., Liao, W., and Pan, W. (2020). Internet use, risk awareness, and demographic characteristics associated with engagement in preventive behaviors and testing: Cross-sectional survey on COVID-19 in the United States. Journal of Medical Internet Research, 22(6), 112. https://doi.org/10.2196/19782

Luo, Y., Yao, L., Zhou, L., Yuan, F., and Zhong, X. (2020). Factors influencing health behaviours during the coronavirus disease 2019 outbreak in China: an extended informationmotivation-behaviour skills model. Public Health, 185(June), 298-305. https://doi.org/10.1016/j.puhe.2020.0 6.057

Mucci, N., Giorgi, G., Roncaioli, M., Perez, J. F., and Arcangeli, G. (2016). The correlation between stress and economic crisis: A systematic review. Neuropsychiatric Disease and Treatment, 12, 983-993. https://doi.org/10.2147/NDT.S98525

Park, C. L., Russell, B. S., Fendrich, M., Finkelstein-Fox, L., Hutchison, M., and Becker, J. (2020). Americans' COVID-19 Stress, Coping, and Adherence to CDC Guidelines. Journal of General Internal Medicine, 35(8), 2296-2303. https://doi.org/10.1007/s11606-02005898-9

Purnami, C. T., and Sawitri, D. R. (2019). Instrumen "Perceive Stress Scale" Online Sebagai Alternatif Alat Pengukur Tingkat Stress Secara Mudah Dan Cepat. Seminar Nasional Kolaborasi Pengabdian Kepada MAsyarakat UNDIP-UNNES, 311-
314.

Restuborg, S. L. D., Ocampo, A. C. G., and Wang, L. (2020). Taking control amidst the chaos: Emotion regulation during the COVID-19 pandemic. Journal of Vocational Behavior, 119. https://doi.org/10.1016/j.jvb.2020.103 440

Roy, D., Tripathy, S., Kar, S. K., Sharma, N., Verma, S. K., and Kaushal, V. (2020). Study of knowledge, attitude, anxiety and perceived mental healthcare need in Indian population during COVID-19 pandemic. Asian Journal of Psychiatry, 51(January). https://doi.org/10.1016/j.ajp.2020.102 083

Spurk, D., and Straub, C. (2020). Flexible employment relationships and careers in times of the COVID-19 pandemic. Journal of Vocational Behavior, 119(January). https://doi.org/10.1016/j.jvb.2020.103 435

Tang, A. C. Y., Kwong, E. W. Y., Chen, L. Y., and Cheng, W. L. S. (2020). Associations between Demographic Characteristics, Perceived Threat, Perceived Stress, Coping Responses and Adherence to COVID-19 Prevention Measures among Healthcare Students in China: A Cross-Sectional Survey with Implications for the Control of COVID19.

MedRxiv. https://doi.org/10.1101/2020.07.15.20 154997v1

Tran, P. B., Hensing, G., Wingfield, T., Atkins, S., Sidney Annerstedt, K., Kazibwe, J., Tomeny, E., Biermann, O., Thorpe, J., Forse, R., and Lönnroth, K. (2020). Income security during public health emergencies: The COVID-19 poverty trap in Vietnam. BMJ Global Health, 5(6), 36. https://doi.org/10.1136/bmjgh2020-002504

Triyanto, E., and Kusumawardani, L. H. (2020). an Analysis of People' S Behavioral Changes To Prevent Covid -19 Transmission Based on Integrated Behavior Model. Jurnal Keperawatan Soedirman, 15(2), 6673.

Webster, R. K., Brooks, S. K., Smith, L. E., 
Woodland, L., Wessely, S., and Rubin, G. J. (2020). How to improve adherence with quarantine: rapid review of the evidence. In Public Health (Vol. 182, pp. 163-169). Elsevier

B.V. https://doi.org/10.1016/j.puhe.2020.0 3.007

WHO. (2020a). Transmission of SARSCoV-2: implications for infection prevention precautions (Issue July).

WHO. (2020b). WHO Coronavirus Disease (COVID-19) Dashboard I WHO Coronavirus Disease (COVID19) https://covid19.who.int/

WHO. (2020c). WHO Director-General's opening remarks at the media briefing on COVID-19 - 11 March 2020. https://www.who.int/directorgeneral/speeches/detail/who-directorgeneral-s-opening-remarks-at-themedia-briefing-on-covid-19---11march-2020

Wiranti, W., Ayun Sriatmi, and Wulan Kusumastuti. (2020). Determinan Kepatuhan Masyarakat Kota Depok terhadap Kebijakan Pembatasan Sosial Berskala Besar dalam Pencegahan Covid-19. Jurnal Kebijakan Kesehatan Indonesia: JKKI, 09(03), 117-124. https://journal.ugm.ac.id/jkki/article/vi ew/58484

Wirawan, G. B. S., and Januraga, P. P. (2021). Correlation of Demographic,
Health Care Availability, And COVID19 Outcome: Indonesian Ecological Study. Frontiers in Public Health, 9(605290).

https://doi.org/10.3389/fpubh.2021.60 5290

Wirawan, G. B. S., Mahardani, P. N. T. Y., Cahyani, M. R. K., Putri, N. L. P. S., Laksmi, and Pande Putu Januragaa, C. (2021). Conspiracy beliefs and trust as determinants of COVID-19 vaccine acceptance in Bali, Indonesia: Cross-sectional study. Personality and Individual Differences, 180(110995).

Zhao, S. Z., Wong, J. Y. H., Wu, Y., Choi, E. P. H., Wang, M. P., and Lam, T. H. (2020). Social distancing compliance under covid-19 pandemic and mental health impacts: A population-based study. International Journal of Environmental Research and Public Health, 17(18), 1-11. https://doi.org/10.3390/ijerph1718669 2

Zhong, B. L., Luo, W., Li, H. M., Zhang, Q. Q., Liu, X. G., Li, W. T., and Li, Y. (2020). Knowledge, attitudes, and practices towards COVID-19 among chinese residents during the rapid rise period of the COVID-19 outbreak: A quick online cross-sectional survey. International Journal of Biological Sciences, 16(10), 1745-1752. https://doi.org/10.7150/ijbs.45221 